\title{
Thermal studies of fly ashes expansion
}

\author{
Wojciech Wons ${ }^{1} \cdot$ Karol Rzepa $^{1} \cdot$ Manuela Reben $^{1} \cdot$ Paweł Murzyn ${ }^{1}$
}

Received: 17 October 2018 / Accepted: 13 March 2020 / Published online: 21 March 2020

(c) The Author(s) 2020

\begin{abstract}
The object of this study is to investigate the thermal properties of fly ashes from the last, farthest dedusting zone in terms of their use as ceramic masses additives. Siliceous fly ash is valuable additive to ceramic mass, which not only reduces its plasticity, but also actively affects sintering process and shapes the properties of the final material. The finest fly ash fractions are potentially useful flux materials in ceramics; however, a significant limitation in their use is due to thermal expansion/ bloating occurring during high-temperature sintering. The bloating mechanism of fly ashes was investigated in relationship to their chemical composition with the use of DTA/TG/EGA analysis as well as high-temperature microscope. Chemical and phase compositions were studied by X-ray fluorescence and X-ray diffraction. Based on the results obtained, it can be concluded. The results indicate that bloating mechanism is caused by the co-occurrence of two phenomena accompanying sintering: appearance of high amount of liquid phase and simultaneous gas release from sintered material. The dominant mechanism is the simultaneous release of sulfur (IV) oxide and oxygen as a result of the redox reaction of removing $\mathrm{SO}_{3}$ from the vitreous phase.
\end{abstract}

Keywords Fly ash $\cdot$ Expansion $\cdot$ Bloating $\cdot$ Thermal studies

\section{Introduction}

Siliceous fly ash is a waste material created during combustion of coal in pulverized coal boilers, accumulated in the dust removal zone [1]. It is used in the building materials industry as a raw material for the production of Portland clinker [2], as an addition to cement [3, 4], mortar [5] and concrete [6-8], as well as sintered ceramic products $[9,10]$. Fly ash was also researched as a starting material for the production of high-degree-of-consolidation and low-porosity ceramics $[11,12]$. This type of material is sintered with a large proportion of the liquid phase at well-defined temperature intervals to avoid thermal softening and/or bloating.

Bloating phenomenon is the result of an intense gas emission from the material during sintering with a large proportion of the liquid phase $[13,14]$. It is also a phenomenon that allows for the production of expanded clay aggregate $[15,16]$. Part of the emitted gases $\left(\mathrm{CO}_{2}\right)$ is the result of oxidation of unburned carbonaceous materials and thermal

Karol Rzepa

krzepa@agh.edu.pl

1 Faculty of Materials Science and Ceramics, AGH University of Science and Technology, Cracow, Poland decomposition of carbonates. Others are the effect of redox reactions (reduction of iron oxides, but also sulfates and sulfides), and some are the result of reactions between clay components and admixtures [17-20]. The gases formed during the reaction cannot escape from the sintered material, which causes bubble creation; however, sufficiently slow heating of the material allows to complete these reactions before sintering and closing the pores [21].

In the case of sintered materials, fly ash is a partial substitute for clay minerals. In addition, due to the increased presence of alkali oxides, they act as a flux that accelerates the sintering process. The presence of alkali generates the formation of a liquid phase during firing, which accelerates mass transport and intensifies sintering. The addition of fly ash to the ceramic mixture allows to lower the temperature of the sintering process $[22,23]$. The fine-grained fly ashes seem to be particularly interesting, because the content of valuable alkali is higher in the smaller fractions and at the same time their surface development is higher, which should be treated as the driving force of the sintering process. Unfortunately, the addition of fine-grained fly ash causes intense bloating of the sintered material, which reduces the safe temperature interval of the process. 
In the case of sintered ceramics, there is also a phenomenon of "black core" associated with expansion, which is caused by the presence of organic compounds as well as reducing oxides [24]. This phenomenon is also found in sintered fly ashes and ceramic materials with the addition of fly ash $[22,23]$.

The aim of this work is to examine the phenomenon of bloating/expansion of fine fly ashes during high-temperature treatment. The performed research focuses mainly on differential thermal analysis and thermogravimetry combined with gas analysis in various measurement atmospheres.

\section{Method of examination}

The subject of the study was two fly ashes (X and Z) taken from two separate power plants based on conventional coal dust furnaces. Dust extraction was carried out with the help of several electrostatic precipitator zones arranged in series behind the combustion chamber. For the purpose of the experiment, only fly ashes from the last, farthest dedusting zone were taken, because these ashes are the most thermally swellable. It is worth noticing that they are the finest and the most interesting fly ashes for ceramic mixtures, in relation to ashes taken from other dust removal zones. Chemical and phase composition of fly ashes were studied with the use of X-ray fluorescence and XRD methods. The chemical analysis of fly ashes was carried out with WD XRF fluorescence spectrometer (Axios mAX Company). Powder diffraction measurements were carried out with the use of PANalytical X'Pert Pro MD diffractometer equipped with $\mathrm{Cu}_{\alpha 1} \mathrm{X}$-ray line with the Bragg-Brentano standard setup comprising a Ge (111) Johansson monochromator at the incidence beam. The scanning range was $10^{\circ}-70^{\circ}$ with 0.008 step size and $20 \mathrm{~s}$ measurement time for each step. A quantitative analysis was carried out using the Rietveld method as described by Le Saout et al. [25]. In order to estimate the amorphous phase, XRD/Rietveld measurement was carried out with corundum as an internal standard. Knowing the percentage of corundum in the sample and the result of Rietveld analysis, the proportion of the glassy phase was calculated. The estimated amount of glassy phase contains crystalline components that are below their detection threshold.

The phenomenon of bloating of fired fly ashes was tested with heating microscope (Hesse Instruments Company). Fly ashes powders were shaped in small cylinders with a height of $3 \mathrm{~mm}$ and a diameter of $3 \mathrm{~mm}$, put inside a small furnace and tested separately. The measurement was carried out in air atmosphere at a constant heating rate of $10{ }^{\circ} \mathrm{C} \mathrm{min}^{-1}$ up to temperature of $1303{ }^{\circ} \mathrm{C}$.

The characteristic temperatures were determined by the samples size and shape change.
The software supplied with the instrument provides sintering curves from which four temperatures can be derived, namely:

1. The first shrinkage or sintering (BS)

2. The maximum shrinkage before softening starts (MS)

3. The softening point, at which the first signal of melting appears (SP)

4. The maximum of bloating-temperature at which the greatest bloating is observed (MB).

Temperatures correspond to a characteristic viscosity point, conventionally determined on the basis of geometrical considerations.

The bloating mechanism was studied with the use of DTA/TG method (thermal differential analysis coupled with thermogravimetry) and the evolved gas analysis EGA.

DTA/TG was performed with the use of STA 449F3 Jupiter Netzsch apparatus in the temperature range between 20 and $1120{ }^{\circ} \mathrm{C}$ at a heating rate of $15^{\circ} \mathrm{C} \mathrm{min}-1$. Average sample masses were between 85 and $95 \mathrm{mg}$, and the $\mathrm{Al}_{2} \mathrm{O}_{3}$-based open crucibles were used. Gas analysis was performed for $\mathrm{m} / \mathrm{z}$ equal to 18 , which corresponds to water secretion (Netzsch STA 449 with mass spectrometer Netzsch QMS 403). Air and helium were used as a carrier gas at a flow rate of $40 \mathrm{~mL} \mathrm{~min}{ }^{-1}$. The apparatus was calibrated in accordance with methodology presented in [26, 27]. The TG/QMS data were analyzed using Proteus software (version 5.2.0) from Netzsch. All the presented curves were corrected against empty runs.

\section{Results}

\section{Chemical characteristic}

The chemical composition of both fly ashes is presented in Table 1.

Fly ashes from both power plants have similar chemical composition, which consist mainly of silicon and aluminum oxides (a total of about 70\%). The remaining part consists of iron oxide, calcium oxide, magnesium oxide and alkaline oxides (potassium and sodium). Fly ash $\mathrm{X}$ contains larger amount of two main oxides in comparison with ash $\mathrm{Z}$ and a smaller amount of other oxides. It is worth noticing that fly ash $\mathrm{Z}$ contains more than $45 \%$ iron oxide, more than $70 \%$ sodium oxide and greater amount of sulfur oxide (Table 1).

In Table 2 and Fig. 1, phase composition of fly ashes is presented.

Both fly ashes consist mainly of glassy phase, which may constitute more than $80 \%$ of the powder mass, according to the used method. The crystalline components of both ashes consist mainly of mullite and quartz but also hematite. 
Table 1 Chemical composition of fly ashes

\begin{tabular}{lll}
\hline Component & \multicolumn{2}{l}{ Content/\%w/w } \\
\cline { 2 - 3 } & Fly ash "X" & Fly ash "Z" \\
\hline $\mathrm{SiO}_{2}$ & 47.85 & 44.85 \\
$\mathrm{Al}_{2} \mathrm{O}_{3}$ & 29.90 & 28.29 \\
$\mathrm{Fe}_{2} \mathrm{O}_{3}$ & 6.50 & 8.00 \\
$\mathrm{CaO}$ & 3.86 & 3.82 \\
$\mathrm{MgO}$ & 2.51 & 2.69 \\
$\mathrm{TiO}_{2}$ & 1.32 & 1.28 \\
$\mathrm{SO}_{3}$ & 1.15 & 2.45 \\
$\mathrm{Na}_{2} \mathrm{O}$ & 2.30 & 5.43 \\
$\mathrm{~K}_{2} \mathrm{O}$ & 2.79 & 2.17 \\
$\mathrm{P}_{2} \mathrm{O}_{5}$ & 1.05 & 0.47 \\
$\mathrm{Rest}$ & 0.77 & 0.55 \\
\hline
\end{tabular}

Table 2 Rietveld refinement phase composition of fly ashes $\mathrm{X}$ and $\mathrm{Z}$

\begin{tabular}{lll}
\hline Phase & \multicolumn{2}{l}{ Content/\%w/w } \\
\cline { 2 - 3 } & Fly ash "X" & Fly ash "Z" \\
\hline Glassy phase & 84.3 & 84.0 \\
Mullite & 11.6 & 9.7 \\
Quartz & 3.5 & 6.5 \\
Hematite & 0.6 & - \\
\hline
\end{tabular}

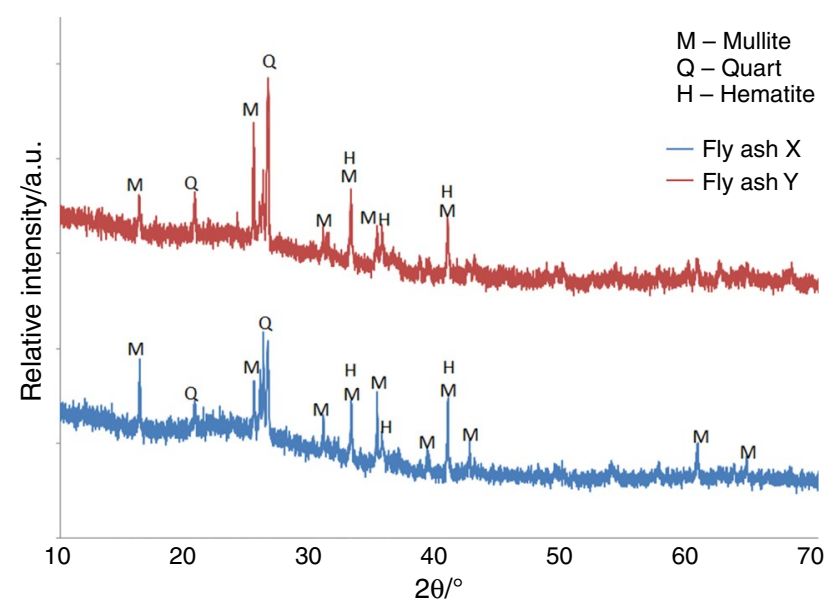

Fig. 1 Phase composition of fly ash $\mathrm{X}$ and $\mathrm{Z}$

\section{Thermal behavior: heating microscope}

In Fig. 2, the area changes of fly ash samples as a function of temperature are shown. The inset shows the heating microscope images registered for both fly ashes tested $\mathrm{X}$ and with their characteristic temperatures, which are: BS - the first shrinkage or sintering; MS - the maximum shrinkage before softening starts; $\mathrm{SP}$-the softening point;

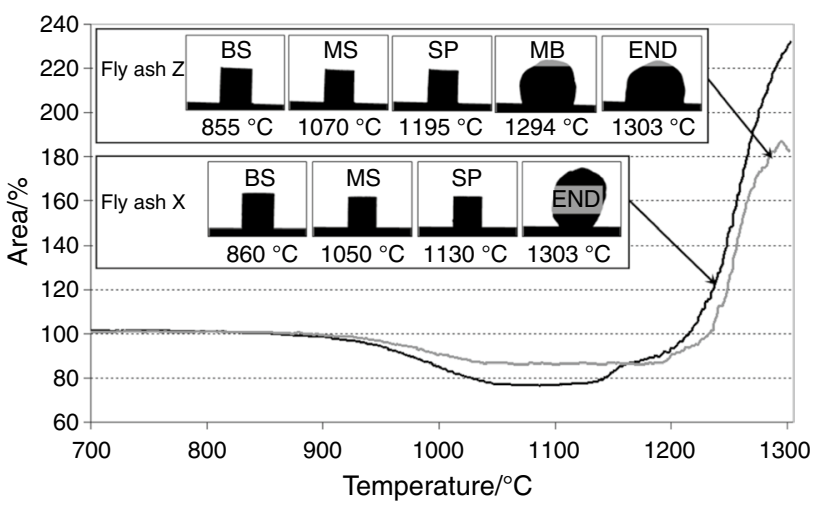

Fig. 2 Area changes of fly ash samples with characteristic temperatures: $B S$ beginning of the sintering, $M S$ maximum of the sintering, $S P$ softening point, $M B$ maximum of bloating, $E N D$ end of measurement

Table 3 Characteristic temperatures of fly ashes samples

\begin{tabular}{lll}
\hline Characteristic temperatures & \multicolumn{2}{l}{ Temperature $/{ }^{\circ} \mathrm{C} /$ change in area/\% } \\
\cline { 2 - 3 } & Fly ash "X" & Fly ash "Z" \\
\hline Beginning of the sintering & $860 / 101.0$ & $855 / 100.8$ \\
Maximum of the sintering & $1050 / 77.2$ & $1070 / 86.0$ \\
Softening point & $1130 / 78.0$ & $1195 / 87.7$ \\
Maximum of bloating & $>1303 />232.0$ & $1295 / 187.2$ \\
\hline
\end{tabular}

${ }^{\text {a }}$ Sample area at a given temperature relative to the initial area of the sample in percentages

MB — maximum of bloating; and END—end of measurement (Table 3).

Both analyzed fly ashes undergo thermal bloating. This process begins at a temperature about $1150{ }^{\circ} \mathrm{C}$, but it is effective only after exceeding the $1200{ }^{\circ} \mathrm{C}$. A greater degree of thermal bloating was recorded for fly ash $X(>230 \%)$ than for ash Z (180\%).

\section{TG/DTA/QMS thermal analysis of fly ashes with gas analysis in synthetic air}

Figures 3-6 present the results of TG, DTG, DTA and the composition of the released gas products $\left(\mathrm{CO}_{2}-\mathrm{m} / \mathrm{z} 44\right.$, $\mathrm{H}_{2} \mathrm{O}-\mathrm{m} / \mathrm{z} 17$ and $\mathrm{SO}_{3} \mathrm{~m} / \mathrm{z} 64$ ) in synthetic air atmosphere, respectively. All the results are presented on the basis of a temperature increase function up to $1100^{\circ} \mathrm{C}$. QMID (quasimulti-ion detection) stands for ion current for various gaseous (volatile) products expressed in amperes.

For both fly ashes in the temperature range between 20 and $200{ }^{\circ} \mathrm{C}$, endothermic effect occurs (Figs. 3, 5) associated with the first mass loss, amounting to approx. $0.26 \mathrm{wt} \%$. The mass loss is caused by the thermodesorption of physically adsorbed water confirmed by the increase in the intensity 


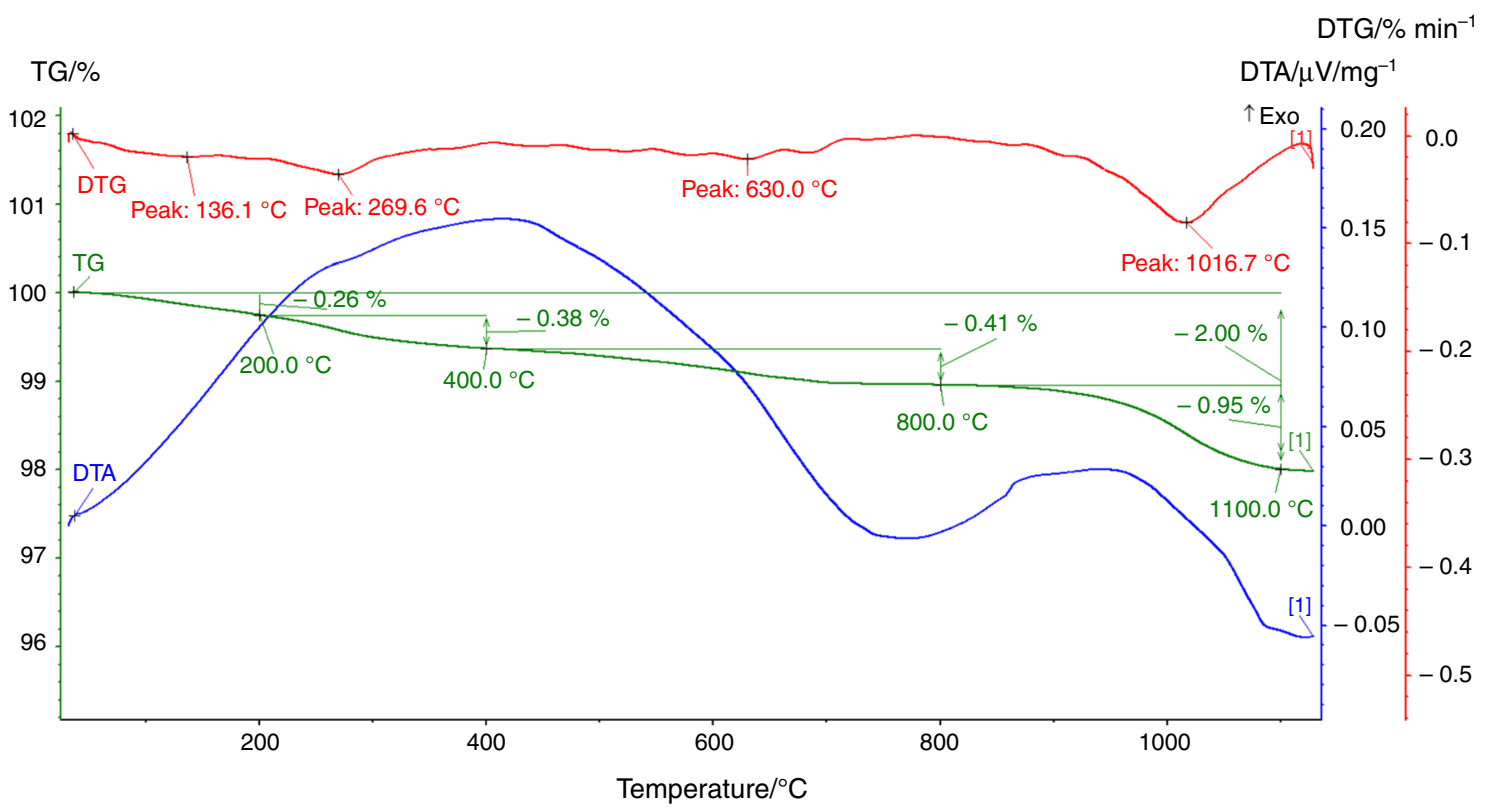

Fig. 3 DTA and TG/DTG curves of fly ash X

of the released gas products (m/z: 17) (Figs. 4, 6). The process of residual carbon combustion starts at the temperature range of $200{ }^{\circ} \mathrm{C}-230{ }^{\circ} \mathrm{C}$. According to DTA curves of fly ash, $\mathrm{X}$ and $\mathrm{Z}$ reflect the occurrence of exothermic effects at $400^{\circ} \mathrm{C}$, which is due to the combustion of residual carbon present in ash. The process is accompanied by a mass loss (TG curve from Figs. 3, 5). This is also proved by the significant increase in signals of $\mathrm{m} / \mathrm{z} 44$ on the recorded gas product curves (Figs. 4, 6).

Moreover, probably the combustion of hydrocarbons takes place, followed by water release. Then, the amorphous carbon (soot) is burned, as well as coke breeze. In the high temperature range of $700-800{ }^{\circ} \mathrm{C}$, endothermic effect took place. It resulted from the thermal dissociation of calcium carbonate $\mathrm{CaCO} 3$ and was responsible for mass loss, amounting to $0.41 \%$ (fly ash X) and $0.42 \%$ (fly ash Z) (see DTA/TG curve in Fig. 3 and DTA/TG curve in Fig. 5). Thermal dissociation of $\mathrm{CaCO} 3$ is proved by the signal enhancement for gas products $\mathrm{m} / \mathrm{z} 44(\mathrm{CO} 2)$ (Figs. 4,6$)$. The most important several subsequent thermal processes take place at temperatures above $800{ }^{\circ} \mathrm{C}$ (Figs. 3, 5). DTA curve of fly ash $\mathrm{X}$ reveals exothermic effect followed by endothermic one. From other studies [28], it is known that among the exothermic effects, the sintering process and the crystallization of fly ash glassy phase are observed, while endothermic effects are associated with the appearance of the liquid

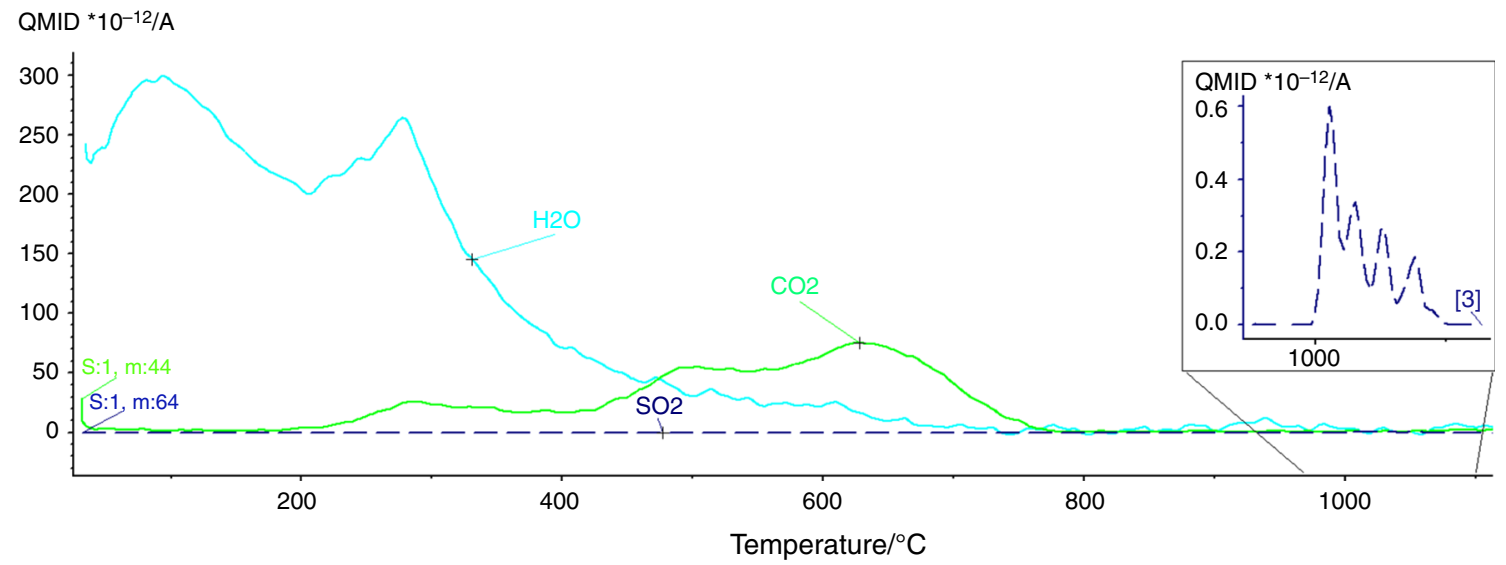

Fig. 4 Analysis of $\mathrm{H}_{2} \mathrm{O}, \mathrm{CO}_{2}$ and $\mathrm{SO}_{2}$ emission during thermal treatment of fly ash $\mathrm{X}$ 


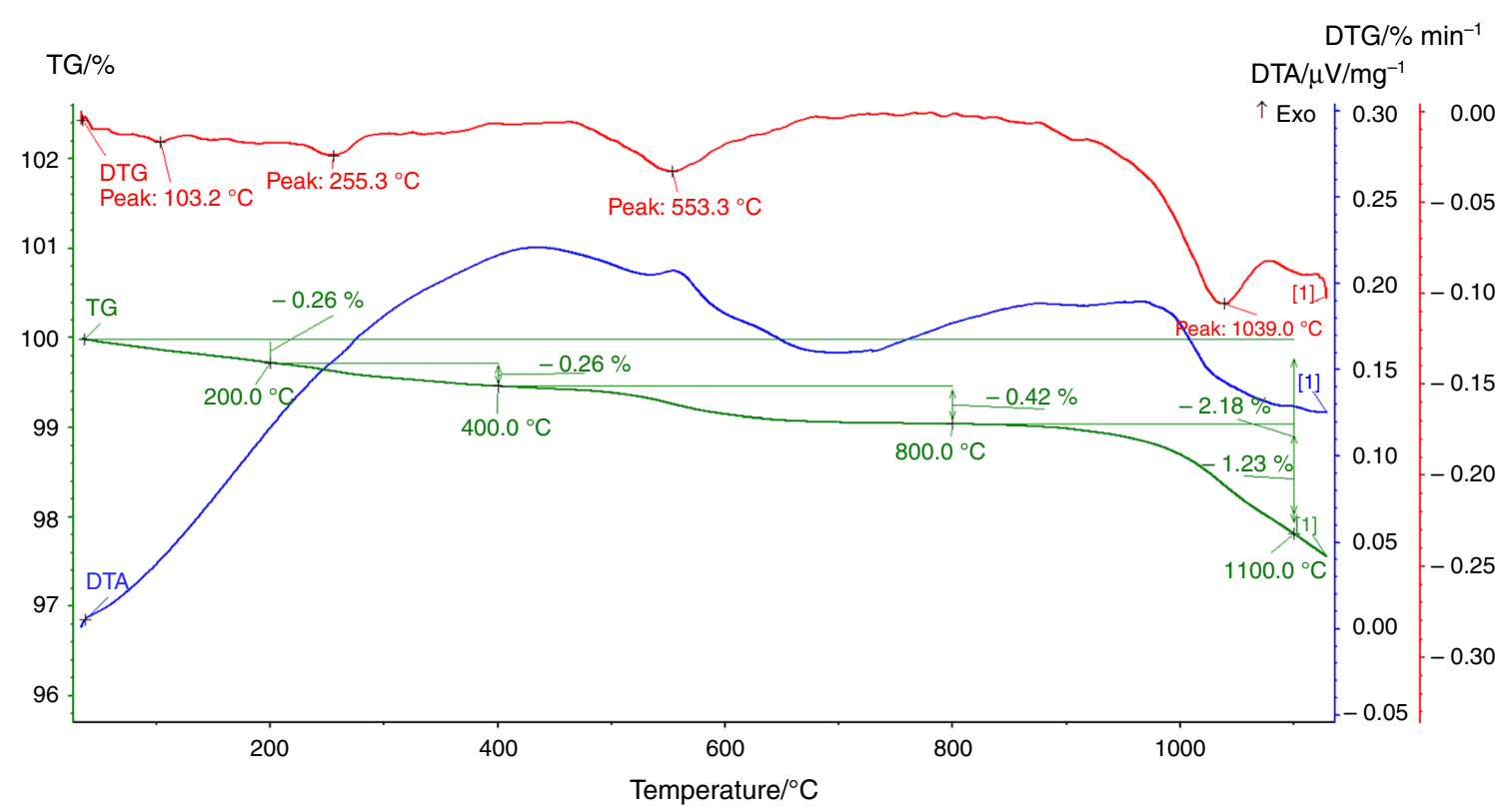

Fig. 5 DTA and TG/DTG curves of fly ash Z

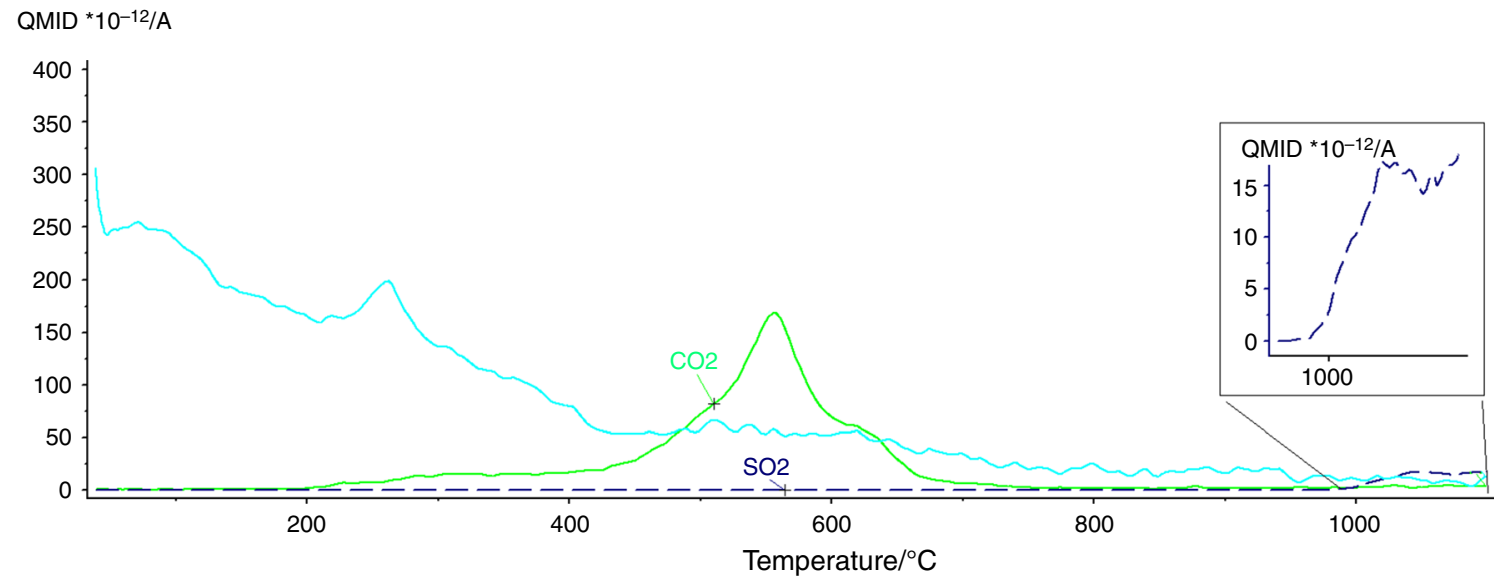

Fig. 6 Analysis of $\mathrm{H}_{2} \mathrm{O}, \mathrm{CO}_{2}$ and $\mathrm{SO}_{2}$ emission during thermal treatment of fly ash $\mathrm{Z}$

phase and probably sublimation process. DTG curves above $800{ }^{\circ} \mathrm{C}$ demonstrated constant mass loss (over 1.5\%). The maximum rate of mass loss is observed at $1016{ }^{\circ} \mathrm{C}$ (fly ash $\mathrm{X}$ ) and $1039^{\circ} \mathrm{C}$ (fly ash Z). The simultaneous increase in the intensity of the released gas products $\left(\mathrm{CO}_{2}-\mathrm{m} / \mathrm{z} 44\right.$ and $\mathrm{SO}_{3}$ $\mathrm{m} / \mathrm{z} 64$ ) is observed (Figs. 4, 6). The registered released gas products of $\mathrm{H}_{2} \mathrm{O}-\mathrm{m} / \mathrm{z} 17$ prove that this loss is connected with moisture evaporation.

The sources of released gases are diverse. One of them is the release of gases closed in fly ash microspheres. This loss of $\mathrm{H}_{2} \mathrm{O}$ and $\mathrm{CO}_{2}$ and $\mathrm{SO}_{2}$ is connected with the process of oxidation of the combustion of coal. The second source may be gas phase reactions. The authors preliminarily assumed that this is the main source of $\mathrm{SO}_{2}$ release from ashes, because the release of this gas occurs only after exceeding the temperature of about $1000{ }^{\circ} \mathrm{C}$.

\section{Thermal analysis of fly ashes with gas analysis in helium atmosphere}

The mass loss (TG curve in Figs. 3, 5) above the temperature of $800{ }^{\circ} \mathrm{C}$ is higher than the mass loss of combustion and mass loss of dehydration effects separately; however, during these two processes, the largest release of gases was recorded (Figs. 4, 6). Probably above $800^{\circ} \mathrm{C}$, gases released cannot be detected in air atmosphere. To address this problem, we performed DTA/TG analysis in which mass loss was monitored while heating fly ashes in a nonoxidizing 


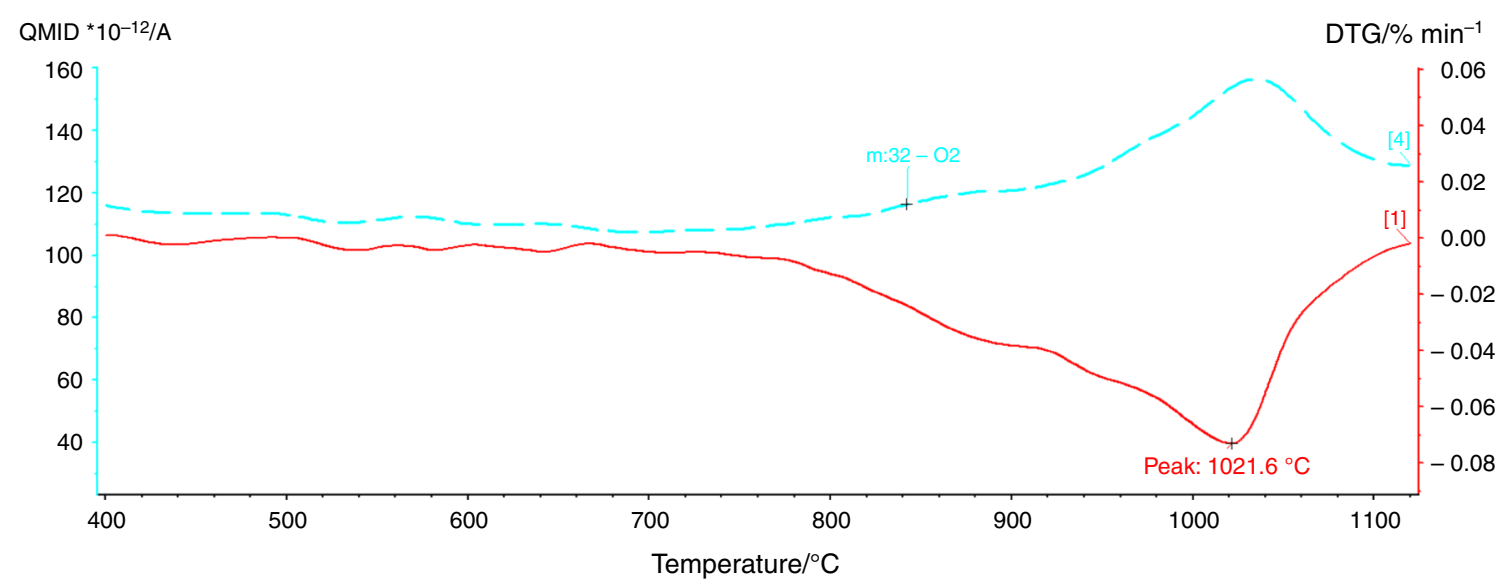

Fig. 7 Oxygen emission and DTG curve during thermal treatment of fly ash X in helium atmosphere

helium atmosphere, followed by heating both samples in an air up to $800{ }^{\circ} \mathrm{C}$. The results of DTG-MS tests are presented in Figs. 7-10 for the $\mathrm{X}$ and $\mathrm{Z}$ fly ashes heated in helium. The released gas products $\left(\mathrm{O}_{2}-\mathrm{m} / \mathrm{z} 32\right.$ and $\left.\mathrm{SO}_{3} \mathrm{~m} / \mathrm{z} 64\right)$ are observed.

By running DTG-MS in different conditions, we found that before the temperature of $800{ }^{\circ} \mathrm{C}$, there was an oxygen desorption from the measuring system and the sample itself (Figs. 7, 9). Oxygen desorption, along with the retention time of helium permeation and temperature was gradually extinguished. After exceeding the temperature of $800{ }^{\circ} \mathrm{C}$, there is a significant increase of oxygen release from the sample. Moreover, after analysis of the MS results, we determined a completely different characteristic of $\mathrm{SO}_{2}$ evolution. In the air, $\mathrm{SO}_{2}$ release starts at about $1000{ }^{\circ} \mathrm{C}$ (Figs. 4, 6), in helium at around $850{ }^{\circ} \mathrm{C}$ (Figs. 8, 10).

Probably, during the thermal treatment, the dominant reaction process that causes emission of oxygen and sulfur dioxide is the decomposition of sulfur trioxide (which is redox reaction, where sulfur is reduced):

$\mathrm{SO}_{3} \leftrightarrow \mathrm{SO}_{2} \uparrow+\frac{1}{2} \mathrm{O}_{2} \uparrow$

This is a conventional reaction, due to the fact that $\mathrm{SO}_{3}$ in the ashes exists in the form of $\mathrm{SO}_{4}^{2-}$ sulfate ion incorporated into the glass. When helium environment was applied during DTG-MS test, the reaction striving for chemical equilibrium is shifted to the right, due to the negligible partial pressure of oxygen. This is due to a lack of oxygen in the measurement atmosphere.

As a consequence, the reaction begins at a lower temperature when the measurement was performed in helium atmosphere, in contrast to that one performed in air, and larger total amount of emitted $\mathrm{SO}_{2}$ was also observed. The $\mathrm{SO}_{2}$ release starts at a temperature of about $1000{ }^{\circ} \mathrm{C}$ (Figs. 4 , 6 ), so it does not coincide with the beginning of temperature

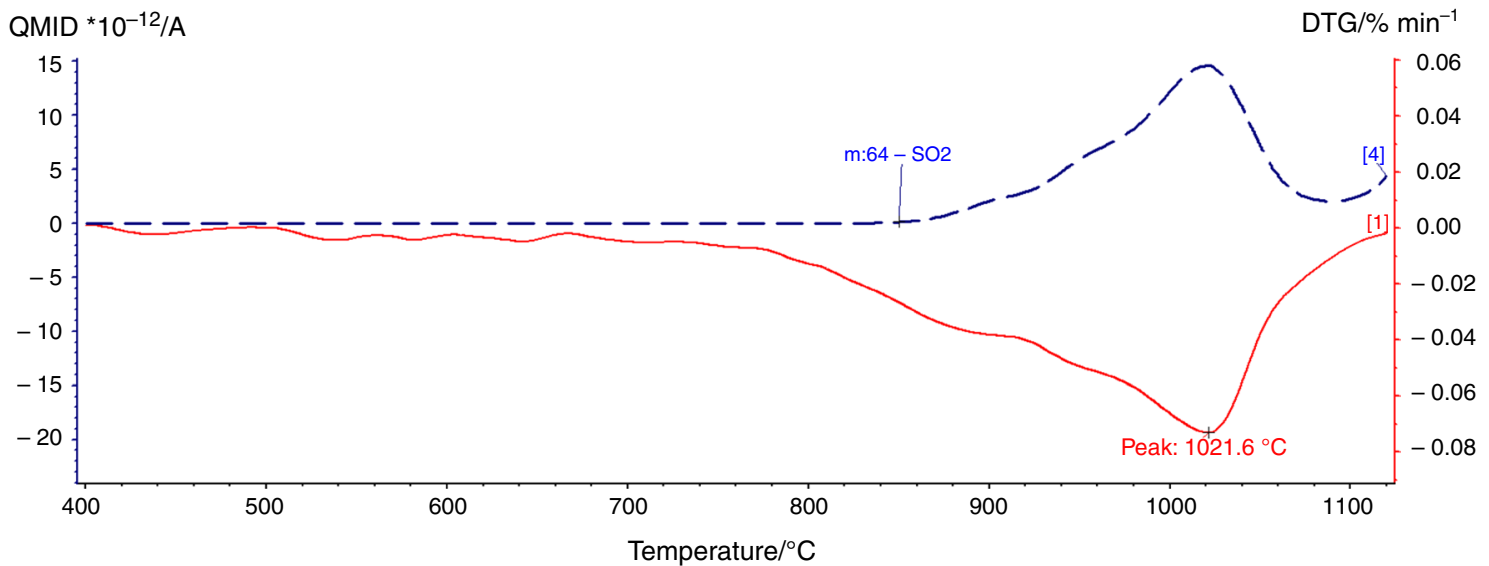

Fig. 8 Emission of $\mathrm{SO}_{2}$ and DTG curve during thermal treatment of fly ash $\mathrm{X}$ in helium atmosphere 


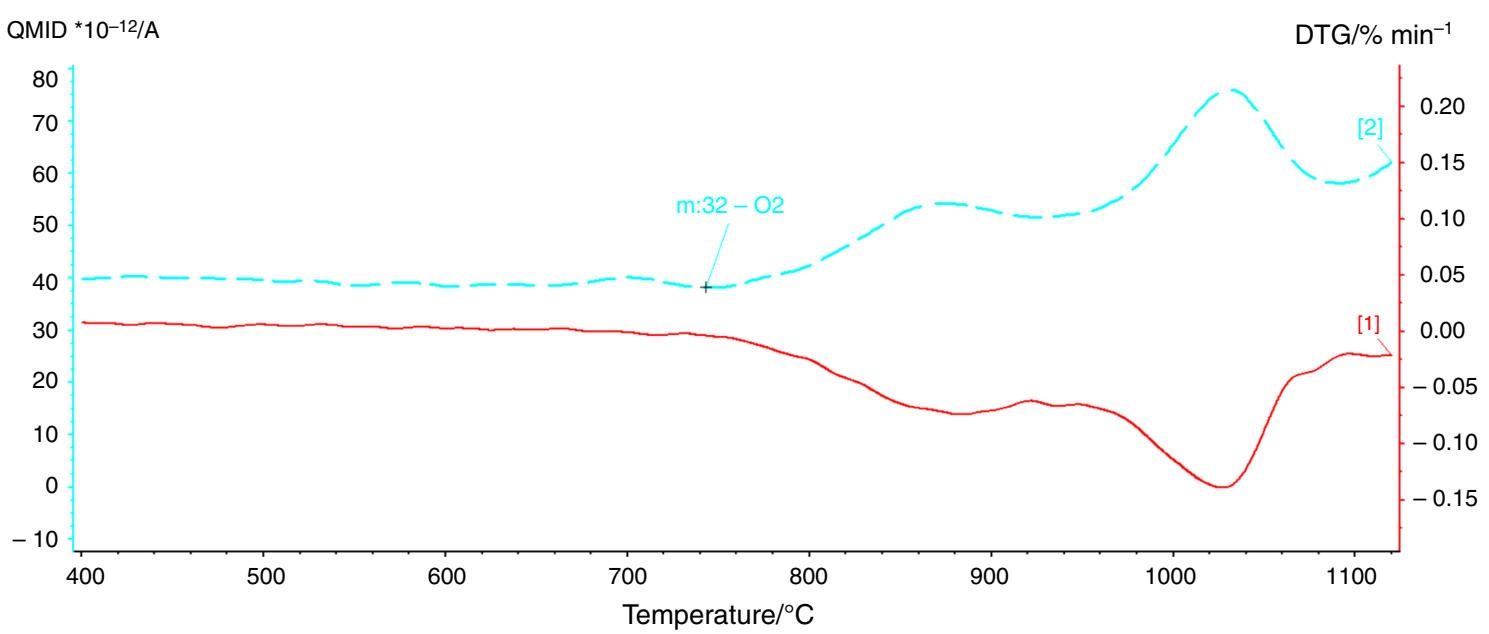

Fig. 9 Oxygen emission and DTG curve during thermal treatment of fly ash $\mathrm{Z}$ in helium atmosphere

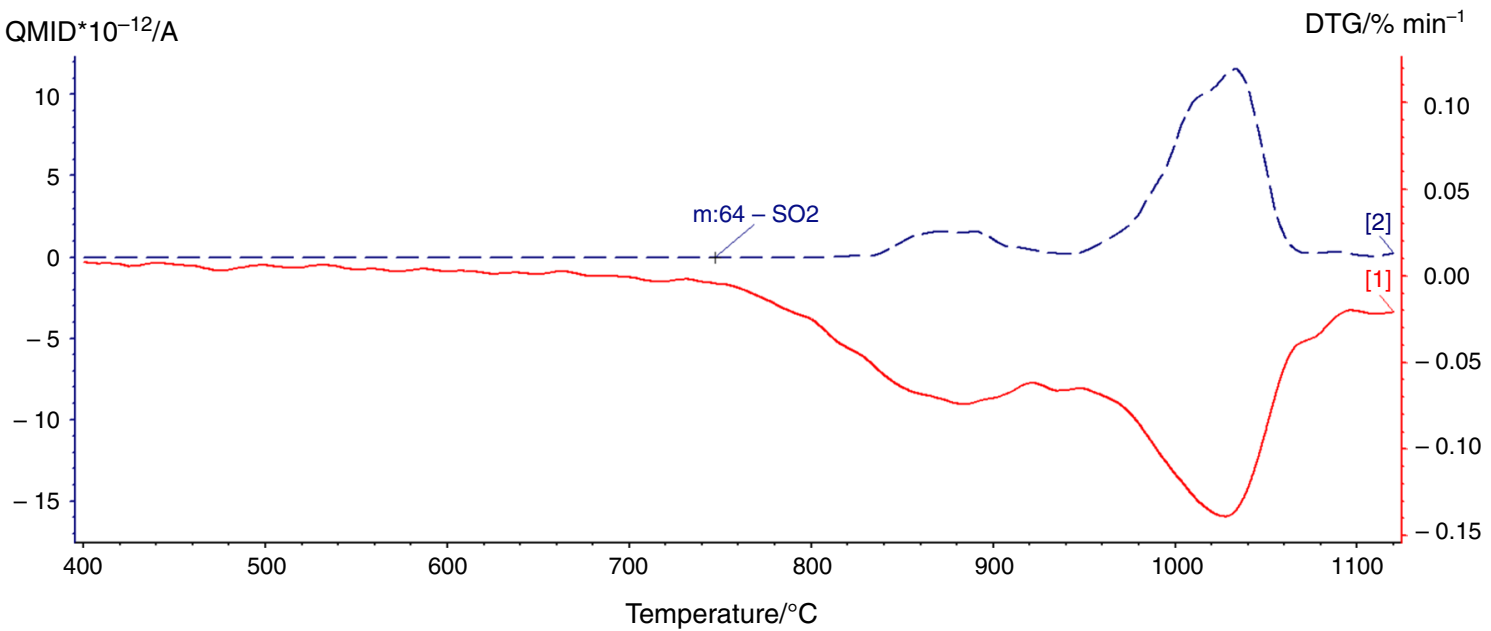

Fig. 10 Emission of $\mathrm{SO}_{2}$ and DTG curve during thermal treatment of fly ash $\mathrm{Z}$ in helium atmosphere

where the mass loss of about $800-850{ }^{\circ} \mathrm{C}$ was observed (TG curves in Figs. 4, 6).

There may be other sources of gas emissions than those mentioned in reaction 1 . If during the thermal treatment only the above reaction would occur, then the shapes and temperature ranges of the $\mathrm{SO}_{2}$ and $\mathrm{O}_{2}$ emission curves should be very similar. There are, however, some deviations which indicate that there may be other oxygen-emitting reaction mechanisms. For example, during the crystallization of the glassy phase of ashes, iron silicates are formed (fayalite) [22]. The presence of this phase is associated with the reduction of iron from +3 to +2 oxidation state, which is accompanied by the process of oxygen emission.

\section{Change in chemical composition during thermal treatment}

Chemical reactions involving the gas phase should cause differences in the chemical composition before and after the reaction. Therefore, fly ash and ash sinters from 1000 and $1100{ }^{\circ} \mathrm{C}$ were subjected to XRF analysis. The results of these analyses are presented in Table 4 in elemental form.

Seemingly, the results do not provide helpful information in explaining the issue of thermal bloating of fly ashes. First, it can be noted that there is less sulfur concentration in the sinters than in the raw ashes. This is particularly visible in the fly ash $\mathrm{Z}$ and the analog sinter from a temperature of $1100{ }^{\circ} \mathrm{C}$. The second important information is the oxygen content in ashes and sinters from a temperature of $1100{ }^{\circ} \mathrm{C}$. Oxygen is the main elemental component of the studied 
Table 4 Change in elemental composition of fly ashes depending on the temperature of sintering

\begin{tabular}{|c|c|c|c|c|c|c|}
\hline \multirow[t]{3}{*}{ Element } & \multicolumn{6}{|c|}{ Content $/ \% \mathrm{w} / \mathrm{w}$} \\
\hline & \multicolumn{3}{|c|}{ Fly ash "X" } & \multicolumn{3}{|c|}{ Fly ash "Z” } \\
\hline & $20^{\circ} \mathrm{C}$ & $1000^{\circ} \mathrm{C}$ & $1100^{\circ} \mathrm{C}$ & $20^{\circ} \mathrm{C}$ & $1000^{\circ} \mathrm{C}$ & $1100^{\circ} \mathrm{C}$ \\
\hline $\mathrm{O}$ & 46.61 & 46.54 & $46.43(47.56)$ & 45.88 & 45.79 & $45.51(46.90)$ \\
\hline $\mathrm{Si}$ & 22.37 & 22.34 & 22.48 & 20.96 & 21.05 & 21.65 \\
\hline $\mathrm{Al}$ & 15.83 & 15.89 & 15.52 & 14.97 & 14.77 & 14.82 \\
\hline $\mathrm{Fe}$ & 4.55 & 4.67 & 4.80 & 5.60 & 5.88 & 6.02 \\
\hline $\mathrm{Ca}$ & 2.76 & 2.78 & 2.88 & 2.73 & 2.93 & 3.03 \\
\hline $\mathrm{Mg}$ & 1.51 & 1.65 & 1.63 & 1.62 & 1.95 & 1.87 \\
\hline $\mathrm{Na}$ & 1.71 & 1.69 & 1.75 & 4.03 & 3.62 & 3.72 \\
\hline K & 2.31 & 2.32 & 2.38 & 1.79 & 1.75 & 1.77 \\
\hline S & 0.46 & 0.31 & 0.27 & 0.98 & 0.80 & 0.07 \\
\hline $\mathrm{Ti}$ & 0.79 & 0.78 & 0.80 & 0.76 & 0.77 & 0.78 \\
\hline rest & 1.10 & 1.03 & 1.06 & 0.68 & 0.69 & 0.76 \\
\hline
\end{tabular}

materials and accounts for almost $50 \%$ of all elements. Taking into account the loss of ignition observed on the TG curves, an increase in the concentration of oxygen should be expected, assuming that it has neither been absorbed nor released. In brackets in Table 4, an estimation of the content of this element is given with the assumptions given above. As can be seen, the real values are more than $1 \%$ lower, which probably confirms that the oxygen was emitted during sintering. In the case of other elements, there were no unambiguous decreases in content, but only a slight increase related to the losses of ignition occurring during sintering of fly ashes.

\section{Conclusions}

Rietveld quantitative X-ray diffraction analysis confirmed that both fly ashes studied consist mainly of glassy phase, which may constitute more than $80 \%$ of the powder mass. The presence of this vitreous phase indicates that a liquid phase is formed during sintering, which enhances the process and causes the shrinkage shown by the HMTA microscope studies. Moreover, fine-grained fly ashes have a high susceptibility to bloating. This phenomenon is favored by the high content of alkali oxides, fine granulation and the large amount of gases released from the liquid phase formed. The onset of the bloating phenomenon recorded by HMTA microscope occurred at much higher temperatures above $1130{ }^{\circ} \mathrm{C}$. This discrepancy is a result of liquid phase occurrence, but on the other hand, it might be connected with a small sample size. The main gases that cause direct thermal bloating are $\mathrm{SO}_{2}$ and $\mathrm{O}_{2}$. By running DTG-MS in different conditions, we found that before the temperature of $800{ }^{\circ} \mathrm{C}$, there was an oxygen desorption from the measuring system and the sample itself. We determined a completely different characteristic of $\mathrm{SO}_{2}$ evolution. When helium environment was applied during DTG-MS test, $\mathrm{SO}_{2}$ release starts at around $850{ }^{\circ} \mathrm{C}$ in comparison with DTG-MS test performed in air where the release of $\mathrm{SO}_{2}$ was observed at about $1000{ }^{\circ} \mathrm{C}$. Moreover, the release of oxygen registered may be the result of redox reaction of iron compounds, e.g., fayalite crystallization, hematite reduction to magnetite. Thermal analysis carried out in a different atmosphere proved that the firing atmosphere itself has a significant effect on the rate and temperature of gas emission. Fine-grained, alkaline-rich fly ashes can then be valuable flux additives in a sintered ceramic. Probably, the addition of suitable oxidants can effectively inhibit the redox reactions and eliminate the phenomenon of bloating.

Acknowledgements This work was supported by the subvention from the Ministry of Science and Higher Education No. 16.16.160.557 in 2019.

Open Access This article is licensed under a Creative Commons Attribution 4.0 International License, which permits use, sharing, adaptation, distribution and reproduction in any medium or format, as long as you give appropriate credit to the original author(s) and the source, provide a link to the Creative Commons licence, and indicate if changes were made. The images or other third party material in this article are included in the article's Creative Commons licence, unless indicated otherwise in a credit line to the material. If material is not included in the article's Creative Commons licence and your intended use is not permitted by statutory regulation or exceeds the permitted use, you will need to obtain permission directly from the copyright holder. To view a copy of this licence, visit http://creativecommons.org/licenses/by/4.0/. 


\section{References}

1. Golewski GL. Improvement of fracture toughness of green concrete as a result of addition of coal fly ash. Characterization of fly ash microstructure. Mater Charact. 2017;134:335-46.

2. Pan JR, Huang C, Kuo JJ, Lin SH. Recycling MSWI bottom and fly ash as raw materials for Portland cement. Waste Manag. 2008;28:1113-8.

3. Weerdt KD, Haha MB, Le Saout G, Kjellsen KO, Justnes H, Lothenbach B. Hydration mechanisms of ternary Portland cements containing limestone powder and fly ash. Cement Concr Res. 2011;3:279-91.

4. EN 197-1:2011. Cement-part 1: composition, specifications and conformity criteria for common cements.

5. Chindaprasirt P, Buapa N, Cao HT. Mixed cement containing fly ash for masonry and plastering work. Constr Build Mater. 2005;19:612-8.

6. Helmuth R. Fly ash in cement and concrete;1987.

7. Lane RO, Best JF. Properties and use of fly ash in Portland cement concrete. Concr Int. 1982;4:81-92.

8. EN 450-1:2012. Fly ash for concrete-part 1: definition, specifications and conformity criteria.

9. Cultrone G, Sebastián E. Fly ash addition in clayey materials to improve the quality of solid bricks. Constr Build Mater. 2009;23:1178-84.

10. Luo Y, Zheng S, Ma S, Liu C, Wang X. Preparation of sintered foamed ceramics derived entirely from coal fly ash. Constr Build Mater. 2018;163:529-38.

11. Karayannis V, Moustatsou A, Domopoulou A, Katsika E, Drossou C, Baklavaridis A. Fired ceramics $100 \%$ from ignite fly ash and waste glass cullet mixtures. J Build Eng. 2017;14:1-6.

12. Castellanos AG, Mawson H, Burke V, Prabhakar P. Fly-ash cenosphere/clay blended composites for impact resistant tiles. Constr Build Mater. 2017;156:307-13.

13. Ayati B, Ferrándiz-Mas V, Newport D, Cheeseman C. Use of clay in the manufacture of lightweight aggregate. Constr Build Mater. 2018;162:124-31.

14. Aineto M, Acosta A, Rincón JMa, Romero M. Thermal expansion of slag and fly ash from coal gasification in IGCC power plant. Fuel. 2006;85:2352-8.

15. Chuang K-H, Lu C-H, Chen J-C, Wey M-Y. Reuse of bottom ash and fly ash from mechanical-bed and fluidized-bed municipal incinerators in manufacturing lightweight aggregates. Ceram Int. 2018;44:12691-6.

16. Dondi M, Cappelletti P, D’Amore M, de Gennaro R, Graziano SF, Langella A, Raimondo M, Zanelli C. Lightweight aggregates from waste materials: reappraisal of expansion behavior and prediction schemes for bloating. Constr Build Mater. 2016;127:394-409.

17. Sfarra S, Perilli S, Paoletti D, Ambrosini D. Ceramic and defects. J Therm Anal Calorim. 2016;123:43-62.

18. Parsons J, Inglethorpe SDJ, Morgan DJ, Dunham AC. Evolved gas analysis (EGA) of brick clays. J Therm Anal. 1997;48:49-62.

19. Lee KG. Bloating mechanism for coal ash with iron oxide. J Korean Cryst Growth Cryst Technol. 2014;24:77-83.

20. Buryan P. Gas generation during Cypris clay expansion. J Therm Anal Calorim. 2018;134:981-92.

21. Rusiecki A, Raabe J. Pracownia technologiczna ceramiki, WSiP 1986.

22. Małolepszy J, Wons W. The influence of the vitreous phase of fly ashes on the sintering process. Materiały Ceramiczne/Ceramic Materials. 2011;63:58-63.

23. Małolepszy J, Wons W. Influence physical and chemical properties of fly ash from hard coal on processes during sintering, 17. ibausil, 17 internationale baustofftagung, Weimar 2009, F. A. Finger-Institut für Baustoffkunde, Bauhaus-Universität, Weimar, Bundesrepublik Deutschland, Tagungsbericht, Bd.2 2009:2-0907-2-0912.

24. Gredmaier L, Banks CJ, Pearce RB. Calcium and sulphur distribution in fired clay brick in the presence of a black reduction core using X-ray fluorescence mapping. Constr Build Mater. 2011;25:4477-86.

25. Le Saout G, Füllmann T, Kocaba V, Scrivener K. Quantitative study of cementitious materials by X-ray diffraction/Rietveld analysis using an external standard. In: 12th International congress on the chemistry of cement Montréal, Canada;2007.

26. Hebda M, Laska M, Szechyńska-Hebda M. Application of a device used for observation of controlled thermal processes in a furnace. J Therm Anal Calorim. 2013;114:1099-109.

27. Hebda M, Gądek S, Skałoń M, Kazior J. Effect of mechanical alloying and annealing on the sintering behaviour of AstaloyCrL powders with $\mathrm{SiC}$ and carbon addition. J Therm Anal Calorim. 2013;113:395-403.

28. Wons W. Wpływ właściwości krzemionkowych popiołów lotnych na proces spiekania mas ceramicznych. Ph.D. Thesis, AGH University of Science and Technology, Kraków, Poland;2010.

Publisher's Note Springer Nature remains neutral with regard to jurisdictional claims in published maps and institutional affiliations. 